\title{
Descriptive Study: Level of Communities Knowledge And Perception About Tuberculosis (TB) in Denpasar, Bali
}

\author{
Ni Putu Ayu Widiasari*, Ida Ayu Jasminarti Dwi Kusumawardani, \\ Ida Bagus Ngurah Rai
}

Pulmonary Disease Study Program Faculty of Medicine Udayana University, Denpasar

\section{ABSTRACT}

Background: Success rate of Indonesia Tuberculosis (TB) treatment did not evenly distribute to every province in 2016, although various program had been carried out by Indonesia Government. Bali's Case Notification Rate (CNR) and Success Rate (SR) of TB also did not reach target in 2017. Successful control of TB can be influenced by community's level of knowledge and perception about TB. Our research objective was to know communities level of knowledge and perception about TB in Denpasar, Bali.

Method: This was cross-sectional research. Our sample was Denpasar communities who visited Puputan Renon Field Car Free Day (CFD) at 25 March 2018. Sample was chosen by consecutive sampling.

Results: Our research result was almost (62\%) of respondent had poor knowledge about TB and $67 \%$ respondent had right perception about TB.

Conclusion: We can conclude that Denpasar communities had poor level of knowledge and good perception about TB.

Keywords: Tuberculosis; Level of Knowledge; Perception

*Correspondence: Ni Putu Ayu Widiasari - ayu.widiasari@yahoo.com

Submitted: September 19 ${ }^{\text {th }} 2020$, Accepted: October 28 ${ }^{\text {th }} 2020$, Published: October $31^{\text {st }} 2020$ 


\section{INTRODUCTION}

Tuberculosis (TB) is an infectious disease caused by infection with the bacteria Mycobacterium tuberculosis. The clinical manifestations of TB are dominated by respiratory complaints due to bacterial tuberculosis infection in the lungs. Other clinical manifestations can include enlarged lymph nodes, pain in the spine, and skin nodules caused by extra-pulmonary TB infection. ${ }^{1}$ Transmission of TB bacteria occurs through droplets excreted by $\mathrm{TB}$ patients when coughing or sneezing. ${ }^{2}$

Today, the TB prevalence rate in the world is still high. In 2016, the World Health Organization (WHO) found that $T B$ is one of the top 10 causes of death globally. Based on WHO's data, in 2016, there were 10.4 million TB sufferers in the world, with an estimated 1 million of them being children. The TB mortality rate in the world in 2016 reached 1.7 million adults and 250,000 children. India, Indonesia, and China are the top three countries with the highest TB prevalence rate globally, where $64 \%$ of TB sufferers are in these countries. This fact shows that Indonesia still has many TB sufferers, especially pulmonary $\mathrm{TB}$, compared to other countries in the world. ${ }^{3}$

In Indonesia, there has been a decrease in TB prevalence rate by $50 \%$ from 1990 to 2015, with an estimate that more than $50 \%$ of cases are individuals aged over 15 years. The quality of the process from finding to diagnosis and the sensitivity of determining the criteria for suspicion also showed a positive development reflected in the increase in the proportion of confirmed pulmonary TB cases. The proportion of confirmed TB cases has increased significantly from 1999 , namely $7 \%$ reaching $14 \%$ in $2015 .{ }^{4}$

A different thing is seen in the success rate of TB treatment in Indonesia. There is a significant difference in numbers between regions, unequal distribution of successful TB treatment. The increase in the incidence of drug-resistant TB in Indonesia is also related to the success of TB therapy. ${ }^{4}$ Nationally, the success rate of TB treatment in Indonesia is $84 \%$, with the highest achievement of 93\% in North Sulawesi province and the lowest in Central Kalimantan, 37\%. ${ }^{5}$

Case Notification Rate (CNR) and Success Rate (SR) are indicators used as benchmarks for TB control in Indonesia. CNR shows the total number of TB patients found and recorded among the 100,000 population, and SR is an indicator showing TB treatment's success. During the past three years, there has been an increase in the CNR of Bali Province to $75 / 100.000$ 
population in 2016, but this figure has not met the targeted CNR of $78 / 100.000 .^{6}$

In 2016, Denpasar's city had the highest CNR rate in Bali at 130, 39 per 100.000 population. The SR figure for Bali Province has also not met the 2016 Strategic Plan for the Health Service and the Ministry of Health. Based on data obtained by the Bali Provincial Health Office in 2017, the achievement of the SR Bali Province in 2016 was only $55.12 \%$, with the target of the Health Office's Strategic Plan $86 \%$ and the Ministry of Health $83 \%$. Denpasar is the city/district with the lowest SR rate in Bali, namely $35.62 \% .^{7}$

The low achievement of the SR with CNR in Denpasar City can be caused by various government and community factors. Government factors relate to promotive, preventive, and curative efforts carried out by the Public Health Center or hospitals. In contrast, community factors include knowledge and perceptions, which then influence people's behavior in dealing with TB infection, especially adherence to treatment. $^{8}$

One of the studies conducted by Pasek et al regarding the relationship between perceptions and knowledge levels of tuberculosis patients with medication adherence in the work area of Buleleng I Public Health Center found that patients with positive perceptions and a good level of knowledge about TB had a $25 \%$ greater likelihood of adhering to treatment than patients with the opposite. ${ }^{8}$ In research conducted by Zaenal S also obtained similar results. ${ }^{9}$

All the facts above indicate the importance of researching public knowledge and perceptions about TB. This study was conducted to know public knowledge and perception about TB, especially in Denpasar, Bali. The research results will later become material for evaluation and consideration of TB control program planning in Denpasar City in particular and Indonesia in general.

\section{METHOD}

This research was conducted at Puputan Renon Field, Denpasar, on the Car Free Day (CFD) activity on Sunday, March 25th 2018 . This research is descriptive quantitative with a crosssectional approach. The study population was all CFD participants at Renon Field on Sunday, March $25^{\text {th }}$, 2018. The inclusion criteria were CFD participants who were domiciled in Denpasar City with the exclusion criteria of participants who refused to fill out a questionnaire and did not read and write fluently. The number of respondents in this study was 100 
people. Sampling was done using consecutive sampling. Data collection was carried out by distributing questionnaires. Informed consent was carried out to determine the availability of respondents filling out the questionnaire. The collected data is then processed using quantitative statistical software.

\section{RESULT}

The number of respondents in this research are 100 people, with the percentage of men $43 \%$, and women $57 \%$.

Table 1. Characteristics of Research Subjects

\begin{tabular}{lc}
\hline \multicolumn{1}{c}{ Variable } & $\%$ \\
\hline Gender: & \\
Male & $43 \%$ \\
Female & $57 \%$ \\
Age: & \\
$\quad$ Productive Age (15-64 years) & $96 \%$ \\
Unproductive age (<15 years or> & \\
64 years) & $4 \%$ \\
Last Education & \\
$\quad$ Elementary School & \\
Junior High School & $3 \%$ \\
Senior High School & $7 \%$ \\
College & $41 \%$ \\
Profession & $49 \%$ \\
$\quad$ Working & \\
Does not working & $62 \%$ \\
Income & $38 \%$ \\
Rp 0,00- Rp 2.363.000,00 & \\
>Rp 2.363.000,00 & $56 \%$ \\
\hline
\end{tabular}

Respondents' ages were grouped by productivity, where respondents aged 15-64 were included in the productive age category, and respondents aged $<15$ or $<64$ were included in the unproductive age criteria. The respondents in this study are dominated by the workers (62\%) and income according to or below the Minimum Wage Districts/Cities (UMK) Denpasar (56\%) (Table 1).

Table 2. Respondents' Knowledge Level of TB

\begin{tabular}{lc}
\hline \multicolumn{1}{c}{ Knowledge level } & Total (\%) \\
\hline Good & $38(38 \%)$ \\
Less & $62(62 \%)$ \\
\hline
\end{tabular}

Table 3. Respondents' Knowledge Level of TB based on Gender, Age Group, Education Level, Occupation, and Income

\begin{tabular}{lll}
\hline \multirow{2}{*}{ Variable } & \multicolumn{2}{l}{ Knowledge Level } \\
\cline { 2 - 3 } & Good Less \\
\hline
\end{tabular}

\section{Gender}

Male

Female

$13(30.2 \%) 30(69.8 \%)$

Age

Productive Age $\quad 38(39.6 \%) 58(60.4 \%)$

Unproductive Age $\quad 0(0 \%) \quad 4(100.0 \%)$

Education

Elementary-Junior $\quad 0(0.0 \%) \quad 10(100.0 \%)$ High School

Senior High $\quad 38(42.2 \%) 52(57.8 \%)$

School-College

Profession

Working 21(33.9\%) $41(66.1 \%)$

Does not working $17(44.7 \%) 21(55.3 \%)$ Income

$\leq$ Rp 2.300.000,00 21 (37.5\%) 35 (62.5\%)

>Rp 2.300.000,00 17 (38.6\%) 27 (61.4\%)

In this study, the average value of respondents' knowledge about TB was 
9.6 with a maximum score of 14 and a minimum score of 3 . Through the normality test the data obtained the distribution of the total data of the respondent's knowledge value is not normal, so the number used as the cutting point of the knowledge level determination is the median total knowledge value. Respondents with a value of $\% 10$ are grouped as respondents with good knowledge and respondents with a value $\leq 10$ are grouped as less knowledgeable respondents. Respondents' knowledge of TB in general, can be seen in Table 2.

Table 4.Categories of Respond Perceptions of TB

\begin{tabular}{lc}
\hline \multicolumn{1}{c}{ Categories of Respond } & Total (\%) \\
\hline Positive & $67(67)$ \\
Negative & $33(33)$
\end{tabular}

In this study, the average respondent's perception of TB was 8.7, with a maximum score of 10 and a minimum score of 2 . After the normality test, it is obtaining that the distribution of the respondent's perception value data is abnormal, so the cut point of the value to determine the respondent category is the median data (9.00).

Respondents with a perceived value of $>9$ were grouped as respondents with positive perceptions, while respondents with a value $\leq 9$ grouped as respondents with negative perceptions. Respondents' perception of TB in general, can be seen in Table 4.

Table 5. Categories of Respondents' Perception of TB based on Gender, Age Group, Education Level, Occupation, and Income

\begin{tabular}{lcc}
\hline \multirow{2}{*}{ Variable } & \multicolumn{2}{c}{ Categories of Respond } \\
\cline { 2 - 3 } & Positive & Negative \\
\hline Gender & & \\
Male & $28(65.1 \%)$ & $15(34.9 \%)$ \\
Female & $39(68.4 \%)$ & $18(31.6 \%)$ \\
Age & & \\
$\quad$ Productive Age & $67(69.6 \%)$ & $29(30.2 \%)$ \\
Unproductive Age & $0(0.0 \%)$ & $4(100 \%)$ \\
Education & & \\
Elementary-Junior & $2(20 \%)$ & $8(80 \%)$ \\
$\quad$ High School & & \\
Senior High & $65(72.2 \%)$ & $25(27.8 \%)$ \\
$\quad$ School-College & & \\
Profession & & \\
Working & $46(74.2 \%)$ & $16(25.8 \%)$ \\
Does not working & $21(55.3 \%)$ & $17(44.7 \%)$ \\
Income & & \\
$\leq$ Rp 2.300.000,00 & $34(58.9 \%)$ & $10(41.1 \%)$ \\
$>$ Rp 2.300.000,00 & $27(77.3 \%)$ & $17(22.7 \%)$ \\
\hline
\end{tabular}

Table 6 showed that the percentage of respondents' answers to each perception statement in the research form. All statements of perception are dominantly answered correctly by the respondents. The two statements with the percentage of the wrong perception, the highest in the statement, "TB is a disease that embarrassing" (32\%) and "TB Treatment should be discontinuing if complaints had improved" (25\%). 
Table 6. Percentage of Perception Category based on Statement on Research Form

\begin{tabular}{|c|c|c|}
\hline \multirow{2}{*}{ Statement } & \multicolumn{2}{|c|}{ Perception } \\
\hline & Positive & Negative \\
\hline TB is an embarrassing disease & $68(68 \%)$ & $32(32 \%)$ \\
\hline $\begin{array}{l}\text { TB patients must be isolated away from society } \\
\text { to prevent contagion. }\end{array}$ & $82(82 \%)$ & $18(18 \%)$ \\
\hline $\begin{array}{l}\text { I checked myself into the public health center } \\
\text { when I had a cough complaint for more than } 2 \\
\text { weeks with fever. }\end{array}$ & $96(96 \%)$ & $4(4 \%)$ \\
\hline $\begin{array}{l}\text { If I have a cough for more than } 2 \text { weeks, I } \\
\text { would rather buy medication at the pharmacy } \\
\text { than check myself into a health facility. }\end{array}$ & $87(87 \%)$ & $13(13 \%)$ \\
\hline I don't need to know information about TB & $93(93 \%)$ & $7(7 \%)$ \\
\hline $\begin{array}{l}\text { Providing TB information to the public is not } \\
\text { necessary. }\end{array}$ & $93(93 \%)$ & $7(7 \%)$ \\
\hline TB is an incurable disease & $89(89 \%)$ & $11(11 \%)$ \\
\hline $\begin{array}{l}\text { If there are families or people in the } \\
\text { neighbourhood are experiencing cough }\end{array}$ & & \\
\hline $\begin{array}{l}\text { complaints more than } 2 \text { weeks with fever, you } \\
\text { would advise them to check with the health } \\
\text { facility. }\end{array}$ & $95(95 \%)$ & $5(5 \%)$ \\
\hline Health checks are not important. & $95(95 \%)$ & $5(5 \%)$ \\
\hline $\begin{array}{l}\text { TB treatment should be discontinued if } \\
\text { complaints are already improved }\end{array}$ & $72(72 \%)$ & $28(28 \%)$ \\
\hline
\end{tabular}

\section{DISCUSSION}

Research on knowledge levels found that $38 \%$ of respondents had good knowledge, and $62 \%$ had less knowledge of TB. Other studies on TB knowledge levels have mixed results. The research conducted by Sandha et al. on the level of knowledge and category of people's perception of Kecicang Karangasem Village against TB got similar results to this study, namely dominant (55.1\%) respondents have less knowledge of TB. ${ }^{10}$
Research conducted by Rahman et al. on TB knowledge in the working area community of Selan Subordinate Health Center, South Kalimantan, also received $50 \%$ of respondents who had less knowledge about TB and only $20 \%$ of respondents who had good knowledge. ${ }^{11}$ In qualitative research conducted by Friskarini et al. regarding adolescents' knowledge and attitude (15-20 years), Tangerang District on TB got the results most teenagers expressed no idea when asked about the symptoms and causes of TB disease. ${ }^{12}$ 
Research conducted by Pasek et al. regarding the knowledge community in the working area of the Buleleng 1 health center regarding TB got different results. The study found dominant respondents (67.5\%) have good knowledge of TB and only $32.5 \%$ have less knowledge about TB. ${ }^{8}$ Research by Siswanto et al. with the population of community respondents in the working area of public health center of Andalas, Padang got $69.2 \%$ of respondents had good knowledge of TB. ${ }^{13}$

The difference in results obtained in some of these studies can be caused by various factors, such as differences in the research methods and characteristics of the respondents used. The research method section consists of the place and time of the research, the design of the research, the size of the sample, the sampling technique, the data collection technique, and the analysis of the data. The research site is part of a research method that clearly looks at the differences in the articles mentioned above. Each region has a diverse level of TB knowledge, where there are areas with dominant communities with good TB knowledge and vice versa. ${ }^{14}$

It gives an idea that there is a gap in people's knowledge levels in some regions of Indonesia regarding $\mathrm{TB}$. Most of the above research are cross- sectional designs, but there are differences in sample size and sampling techniques. The sample size in the research mentioned above varies. The sample size affects the bias obtained in the results of the study and the suitability of the results of the study to the reality in the field. ${ }^{14}$

So, the difference in the study results in some of these studies can be caused by bias due to the small size of the sample and the difference in characteristics of the respondents used. The characteristics of respondents can also affect the level of knowledge. According to Notoatmojo, the level of knowledge can be influenced by community characteristics such as education level, occupation, and age. ${ }^{14}$

This research has been conducted on data analysis level of knowledge by gender, age group, education level, occupation, and income shown in table 4. There was no difference in the distribution of knowledge levels based on gender, age, education, employment, and income in this study.

Research by Sandha et al found a difference in the distribution of TB knowledge levels based on age, education, and employment. Respondents of unproductive age, dominant (66.7\%) have less knowledge of TB, while productive age respondents, dominant (54.3\%), have 
a good knowledge of TB. Respondents who have a background in the study of elementary and junior high school education and respondents who do not work dominantly have less knowledge about TB. Respondents with a background of high school education, college, and work dominantly have a good knowledge of TB. Research conducted by Selleca in 2012 showed that a relationship of economic status (income) with TB knowledge levels and delays in TB diagnosis. ${ }^{10,15}$

According to Notoatmodjo, age is one of the factors that can influence knowledge. This is related to changes in psychological aspects and maturity of thinking with age, thus affecting the ability to capture and process information. The level of education is also an essential factor that can affect knowledge. According to Notoatmojo, the higher the level of individual education, it will be easier for the individual to receive and develop the information or knowledge received. Employment and economic status are two things that are related and can affect knowledge levels. ${ }^{14}$

Employment and economic status can affect the process of accessing information and exposure to dominant information in individuals. Individuals who work logically will get easier exposure to information than individuals who don't work. Individuals working in the health field will have a better level of health knowledge than individuals who do not work in health areas related to information exposure. In this study, there was no difference in the distribution of knowledge levels based on age, education level, occupation, and income due to the number of different respondents in each group and there were groups with fewer than ten respondents.

Low levels of community TB knowledge can affect the success of TB prevention in an area. The success of TB treatment is influenced by a variety of factors, such as preventive measures of TB transmission, speed of diagnosis, and successful treatment. Preventive measures on TB can be optimized if the public knows and understands about TB transmission patterns. The speed and accuracy of diagnosis can also be influenced by the level of knowledge of the community. In the study conducted by Selleca, it was found patients with low TB knowledge levels also had an average delay in first visits to primary health facilities of 128.84 days compared to patients with high TB knowledge..$^{15}$

The drug-taking adherence of TB patients strongly influences the success of TB treatment. The level of knowledge can also affect the 
compliance of the patient's treatment. In the study conducted by Siswanto et al. obtained the level of patient knowledge about TB significantly related $(p=0,000)$ to the level of treatment compliance. TB patients with an adequate level of knowledge have a good level of compliance, and vice versa. In the study also obtained, in addition to the level of knowledge, family support also influenced the patient's compliance in undergoing treatment. ${ }^{13}$

Other studies conducted by Muture et al. in the population in Nairobi Province, Kenya through multivariate analysis obtained, significantly less knowledge of TB (OR 8.67\%; 95\% CI 1.47-51.3) compliance affected the drug-taking of TB patients. ${ }^{16}$ Research conducted by Paixao et al. in populations in southeastern Brazil found that the quality and quantity of information about TB disease held by respondents was related to drop out cases in TB patients. In the study, patients with fewer details about TB had a higher risk of drop out than patients with good information about TB. ${ }^{17}$ Research by Vijay et al. in India also gained through poor knowledge that TB affects the treatment compliance of TB sufferers with AOR-1.88 (1.35-2.63). ${ }^{18}$
The facts above can provide an overview of the causes of CNR and SR Bali that have not reached the target in 2016. The low level of public knowledge can affect various aspects of TB management process, especially in Bali. The increase in knowledge about TB can be done by providing information about TB to the public.

Based on qualitative research conducted, Friskarini et al., the majority of respondents did not know the ways of transmission of TB and prevention of TB. Most of the respondents said transmission of TB due to a virus and can be transmitted through glass or plate that is used together with TB patients. The study also found that most respondents had low knowledge of TB symptoms. The dominant respondent said coughing up blood as a symptom of $T B$, while other $T B$ symptoms were unknown. ${ }^{11}$

In the study by Sandha et al. got similar results. The dominant respondents had less knowledge about the risk factors and causes of TB as well as TB prevention. This fact can be due to the incomplete provision of information about TB to the public. ${ }^{10}$

The results of public perception research on TB found that $67 \%$ of respondents had a positive perception of $\mathrm{TB}$, and $33 \%$ had a negative perception of TB. Different perception 
categories of gender, age group, education level, occupation, and income can be seen in table 7 . Respondents with an unproductive age all had negative perception categories of $\mathrm{TB}$, while respondents with the dominant productive age had a positive perception of TB (69.6\%). Respondents with the background of the study of dominant elementary and junior high schools had negative perceptions of TB (80\%). In comparison, respondents with the background of the study of senior high school and college dominantly had a positive perception of TB (72.2\%).

Other studies on public perceptions of TB have had mixed results. Research conducted by Sandha et al. in Kecicang Village, Karangasem, found that most respondents (67.3\%) had positive perceptions about TB. In this study, there was no difference in the distribution of perception categories based on the respondent's age, education level, occupation, and respondent's income. ${ }^{10}$ Another study conducted by Pasek et al. In 2013, in Buleleng 1 Public Health Center's work area, found that $82.5 \%$ of respondents had positive perceptions about TB. ${ }^{8}$

The qualitative research conducted by Friskarini et al. on adolescents aged 15-20 years in Tangerang District obtained different results. In this study, most of the informants believed that pulmonary TB was not a dangerous disease, which in turn could affect the emergence of a lack of care about pulmonary TB disease. ${ }^{12}$ Qualitative research conducted by the Media in Sungai Tarab District, Tanah Datar Regency, West Sumatra Province, found that most respondents had the wrong perception about TB. In the Focus Group Discussion (FGD) activity conducted, most respondents believed that TB is a disease caused by black magic and heredity. Most informants also thought that TB symptoms were commonplace and did not require particular therapy, making it late for them to go to health services. ${ }^{19}$

The facts above show different categories of public perceptions about TB in several regions in Indonesia. There are several areas with community dominance that have negative perceptions about TB. Public perception can influence the success of TB control programs, especially in Indonesia. One of TB management's essential factors that can be influenced by public perceptions complies with TB patients' medication. In a study conducted by Putera et al. On a population in the Province of East Nusa Tenggara (NTT), it was found that knowledge and perceptions influenced 
TB patient medication adherence. In the multivariate analysis, only people's perceptions of TB significantly affected TB patient medication adherence with OR (95\% confidence interval (CI)) 4.75 (2.30-9.86) p <0.001, while for demographic characteristics and knowledge about TB did not have a significant effect. ${ }^{20}$

Research conducted by Pasek et al. found that patients with positive perceptions of TB were 21.41 times more likely to adhere to treatment with $p=0.018$ than patients with negative perceptions. In another study, it was stated that apart from knowledge and perceptions of TB, alcoholism, expensive health facilities, the presence of a family with $T B$, age and marital status, and monthly income were related to TB treatment adherence. ${ }^{8}$

In a study conducted by Sandha et al., the perception statement in the form of "TB is a shameful disease" is the dominant statement answered with respondents' negative perceptions. Other statements that were predominantly answered with negative perceptions by respondents were statements about the respondent's awareness of having a complaint and the cost of TB examination at the Public Health Center and hospitals, classified as expensive. This fact can illustrate the low achievement figures for the CNR and SR, especially in Bali. ${ }^{10}$ CNR and SR were influenced by patient arrival for self-examination and adherence to medication. If most people still believe that TB is an embarrassing disease, TB drugs can be stopped when complaints improve. Delays in checking into health services, the risk of late diagnosis, disease transmission, treatment noncompliance, and drug resistance is high.

In several studies, it was said that there was a relationship between the level of knowledge and public perceptions of TB. Therefore, one of the actions that can change negative perceptions into positive ones is to increase knowledge. In a study conducted by Putra et al., it was stated that the cause of the low individual's knowledge of TB was the absence of a family history of TB and never reading or attending TB education activities. ${ }^{20}$

Therefore, providing information about TB to the broader community is one method that can be used to increase public knowledge and perceptions about TB. Education and personal provision of information by health workers to TB patients and their families is also a way to increase public knowledge and perceptions about TB.

This study's weakness is because the researcher does have no data on the history of exposure to TB 
information on the respondent, which consists of information media and TB information material that has been obtained. The relationship between knowledge, perception, and the history of receiving information about TB in the respondent is not known. The researcher has not divided the respondent's level of knowledge based on the type of question in the questionnaire, not to know which the respondent does not understand the category of TB information.

\section{CONCLUSION}

In this study, it was found that $38 \%$ of respondents had good knowledge, and $62 \%$ of respondents had less knowledge about TB. There were no differences in the distribution of knowledge levels based on age, sex, education level, occupation, and income.

The category of respondents' perceptions of TB was dominant. It was found that $67 \%$ of respondents had positive perceptions about TB, and 33\% of respondents had negative perceptions. All non-productive (100\%) respondents have negative perceptions of $\mathrm{TB}$, while the dominant respondents of productive age (69.6\%) have positive perceptions about TB. Respondents with a dominant Elementary-Junior High School education level (80\%) had a negative perception of TB. In comparison, respondents with a dominant Senior High School-College education level $(72.2 \%)$ had a positive perception of TB.

Suggestions for further research are researching public knowledge and TB perceptions with more comprehensive area coverage and sample size. Further research is needed on the factors that influence the level of knowledge and public perceptions about TB, including the effect of providing information on knowledge. Further research is needed on the factors that influence the success of TB control, especially in Indonesia.

\section{REFERENCES}

1. Campo M, Kawamura LM. What is Tuberculosis (TB)? American Journal of Respiratory and Critical Care Medicine. 2017;195(4):P7P8. doi:10.1164/rccm.1954P7

2. Narasimhan P, Wood J, Macintyre $C R$, Mathai D. Risk factors for tuberculosis.

Pulmonary Medicine. 2013;2013:11.

3. World Health Organization (WHO). Tuberculosis. https://www.who.int/newsroom/factsheets/detail/tuberculosis. Published 2018. Accessed March 
30, 2018.

4. Adiwinata R, Rasidi J, Marpaung M. Clinical Profile and Treatment Evaluation of RifampicinResistant and Multidrug-Resistant Tuberculosis Patients at Dr. $J$ Respir Indo. 2018;38(3):135142.

5. Pusdatin Kementrian Kesehatan. Tuberkulosis: Temukan Obati Sampai Sembuh. Jakarta: Kementrian Kesehatan; 2016.

6. Dinas Kesehatan Provinsi Bali. Profil Kesehatan Provinsi Bali Tahun 2016. Denpasar: Dinas Kesehatan Provinsi Bali; 2017.

7. Dinas Kesehatan Kota Denpasar. Profil Kesehatan Kota Denpasar Tahun 2016. Denpasar: Dinas Kesehatan Kota Denpasar; 2017.

8. Pasek MS, Suryani N, Murdani P. Hubungan Persepsi dan Tingkat Pengetahuan Penderita Tuberkulosis dengan Kepatuhan Pengobatan di Wilayah Kerja Puskesmas Buleleng 1. Jurnal Magister Kedokteran Keluarga. 2013;1(1):14-23.

9. $S M Z$, Muljono $P$, Sugihen BG, Susanto D. Faktor-Faktor Yang Berpengaruh Terhadap Kepatuhan Pengobatan Penderita Tuberculosis (TB) Pada Program Community Tb Care Aisyiyah Kota Makassar. Jurnal Penelitian
Komunikasi dan Pembangunan. 2018;19(2):129-142.

10. Sandha LMH, Sari KAK. Tingkat Pengetahuan dan Kategori Persepsi Masyarakat Terhadap Penyakit Tuberkulosis (TB) di Desa Kecicang Islam Kecamatan Bebandem Karangasem-Bali | EJurnal Medika Udayana. E-Jurnal Medika Udayana. 2017;6(12):131-139.

11. Rahman F, Adenan A, Yulidasari F, Laily N, Rosadi D, Azmi AN. Pengetahuan Dan Sikap Masyarakat Tentang Upaya Pencegahan Tuberkulosis. Media Kesehatan Masyarakat Indonesia. 2017;13(2):183. https://journal.unhas.ac.id/index .php/mkmi/article/view/1993.

12. Friskarini $\mathrm{K}$, Manalu HS. Pengetahuan Dan Sikap Tentang Penyakit Tb Paru Pada Remaja Di Kabupaten Tangerang Tahun 2009. Buletin Penelitian Kesehatan. 2014;42(1):37-45.

13. Siswanto IP, Yanwirasti $Y$, Usman E. Hubungan Pengetahuan dan Dukungan Keluarga dengan Kepatuhan Minum Obat Anti Tuberkulosis di Puskesmas Andalas Kota Padang. Jurnal Kesehatan Andalas. 2015;4(3).

14. Notoatmodjo S. Pendidikan Dan Perilaku Kesehatan. Jakarta: 
Rineka Cipta. 2003. Jakarta:

Rineka Cipta; 2003. doi:in:

Sandha LMH, Sari KAK. Tingkat

Pengetahuan dan Kategori

Persepsi Masyarakat Terhadap

Penyakit Tuberkulosis (TB) di

Desa Kecicang Islam Kecamatan

Bebandem Karangasem-Bali. EJournal Medika. 2017;6:131-9.

15. Selecca CS. Hubungan status ekonomi dan tingkat pengetahuan TB dengan keterlambatan pasien dalam diagnosis kasus TB paru. 2013.

16. Muture BN, Keraka MN, Kimuu PK, Kabiru EW, Ombeka VO, Oguya F. Factors associated with default from treatment among tuberculosis patients in nairobi province, Kenya: A case control study. BMC Public Health. 2011;11.

17. Paixão LMM, Gontijo ED. Profile of notified tuberculosis cases and factors associated with treatment dropout. Revista de Saude Publica. 2007;41(2):205-213.

18. Vijay S, Kumar P, Chauhan LS, Vollepore BH, Kizhakkethil UP, Rao SG. Risk factors associated with default among new smear positive TB patients treated under DOTS in India. PLOS ONE. 2010;5(4).
19. Media Y. Pengetahuan, Sikap Dan Perilaku Masyarakat Tentang Penyakit Tuberkulosis (TB) Paru Di Kecamatan Sungai Tarab, Kabupaten Tanah Datar Propinsi Sumatera Barat. Media Litbang Kesehatan. 2011;21(2):82-88.

20. Putera I, Pakasi TA, Karyadi E. Knowledge and perception of tuberculosis and the risk to become treatment default among newly diagnosed pulmonary tuberculosis patients treated in primary health care, East Nusa Tenggara: A retrospective study. BMC Research Notes. 2015;8(1):238. 